\title{
VESICULAR ARBUSCULAR MYCORRHIZAL SPORE POPULATIONS IN VARIOUS SASKATCHEWAN SOILS AND THE EFFECT OF INOCULATION WITH Glomus mosseae ON FABA BEAN GROWTH IN GREENHOUSE AND FIELD TRIALS
}

\author{
R. M. N. KUCEY' and E. A. PAUL' \\ 'Agriculture Canada Research Station, Lethbridge, Alberta T1J 4B1; and \\ 2Department of Plant and Soil Biology, University of California, Berkeley, Cali- \\ fornia 94721. Received 10 May 1982, accepted 20 Sept. 1982.
Kucey, R. M. N. And Paul, E. A. 1983. Vesicular arbuscular mycorrhizal spore populations in various Saskatchewan soils and the effect of inoculation with Glomus mosseae on faba bean growth in greenhouse and field trials. Can. J. Soil Sci. 63: 87-95.

\begin{abstract}
The numbers of vesicular arbuscular mycorrhizal spores in various Saskatchewan soils, and the effect of Glomus mosseae inoculation on the growth of faba beans (Vicia faba) were studied. The size of the mycorrhizal spore population varied from site to site, but in general, more spores were found in undisturbed soils than in adjacent cultivated soils. Practices which reduced the density of potential host roots also reduced the numbers of spores found in the soil. Inoculation of faba beans with $G$. mosseae spores resulted in increased dry matter production both in growth chamber and field studies in the presence of indigenous mycorrhizal spores. Inoculation also resulted in higher levels of root colonization and increased total phosphorus uptake.
\end{abstract}

Key words: Mycorrhizae, faba bean, phosphorus, spore, colonization, soil

\begin{abstract}
[Populations de spores vésiculo-arbusculaires de mycorhizes dans divers sols de la Saskatchewan et l'effet de I'inoculation par Glomus mosseae sur la croissance de la féverole dans des essais en serre et en plein champ.]

Titre abrégé: Spores VAM et inoculation.

On a étudié le nombre de spores vésiculo-arbusculaires de mycorhizes dans divers sols de la Saskatchewan et l'effet de l'inoculation par Glomus mosseae sur la croissance de la féverole (Vicia $f a b a$ ). La taille de la sporée mycorhizienne varie d'un emplacement à l'autre, mais en général, les sols non remaniés contiennent plus de spores que les sols travaillés voisins. Les pratiques qui réduisent la densité racinaire d'hôtes potentiels réduisent également le nombre de spores retrouvées dans le sol. L'inoculation de la féverole avec des spores de G. mosseae accroît la production de matière sèche, tant dans les études en chambre de croissance qu'en plein champ, en présence de spores mycorhiziennes indigènes. L'inoculation intensifie également la colonisation radiculaire et augmente l'absorption totale de phosphore.
\end{abstract}

Mots clés: Mycorhize, féverole, phosphore, spore, colonisation, sol

The extent to which spores of vesicular arbuscular mycorrhizal (VAM) fungi present in a soil reflect the inoculum potential of that soil is uncertain, however, spores do appear to be the most likely propagule for VAM survival over adverse climatic periods (Smith 1980). The number of VAM Can. J. Soil Sci. 63: 87-95 (Feb. 1983) spores found in a soil depends on many factors including light intensity, temperature (Furlan and Fortin 1973, 1977; Schenck and Schroder 1974), season (Saif and Khan 1975), plant defoliation (Daft and El Giahmi 1978), soil depth, pH, texture, moisture, and organic matter content (Saif et al. 1975; Sheikh et al. 1975). With 
the exception of phosphorus fertility, those factors that increase plant growth generally increase fungal colonization and spore production.

The interaction between phosphorus and VAM fungi is an aspect of the plant-fungus symbiosis that has been extensively studied. Generally, the number of mycorrhizal spores, the levels of mycorrhizal root colonization, and the benefits derived from the symbiosis decline in a soil as phosphorus availability increases (Ross 1971; Hayman et al. 1975).

Plant growth has been increased by VAM colonization in many studies (Maronek 1981). VAM symbioses have also been found that either do not increase host growth or, in some cases, even decrease plant growth under certain conditions of growth, depending on the particular hostfungus symbiosis, and even these fungal relationships often result in increased plant concentrations of $\mathrm{P}, \mathrm{K}, \mathrm{Ca}, \mathrm{Fe}, \mathrm{Zn}, \mathrm{Cu}$ and S (Gerdemann 1964; Rhodes and Gerdemann 1978; Lambert et al. 1979).

Several experiments have been conducted to test the effect of different VAM fungal species on plant responses. Powell (1977) found that mycorrhizal treatments increased the percent $P$ found in clover shoots to above that found in the control shoots. In 17 of 20 cases, indigenous fungi raised the shoot $P$ concentrations above the levels obtained for plants infected with introduced species. Yield data showed increases in shoot dry matter with colonization.

Powell and Daniel (1978) used five soils, three introduced species of VAM fungi, and two levels of added P to study the growth of white clover in pots. Contrary to the above study, clover plants colonized by introduced fungi produced larger shoots than those colonized by indigenous fungi in 16 of 30 possible combinations. Certain combinations yielded greater positive responses to colonization in soils with low P levels. Plants colonized by Glomus fasciculatus Thax. were smaller than those colonized with indigenous fungi in a nonamended silt soil, but grew much larger if $P$ was added to the soil.

This study was undertaken to determine the number of VAM spores present in cultivated and virgin soils of central and eastcentral Saskatchewan and the effect of summer-fallowing, season, and P fertilization on the VAM spore populations. The effect of introduction of an isolate of $G$. mosseae (Nicol and Gerd.) on the yields of faba beans in nonsterile growth chamber and field soil was also studied to determine if selected mycorrhizal fungi could be used to increase crop yields above that promoted by indigenous mycorrhizal fungi.

\section{MATERIALS AND METHODS}

\section{VAM Spore Enumeration and Root Coloni-} zation Evaluation

Soil samples from the field or pot experiments (described below) were thoroughly mixed. Three 100-g samples of wet soil were removed for spore analysis and one for moisture content determination (dried $24 \mathrm{~h}$ at $85^{\circ} \mathrm{C}$ ). Samples for spore analysis were washed through a $240-\mu \mathrm{m}$ sieve (60 mesh) and a $63-\mu \mathrm{m}$ sieve ( $230 \mathrm{mesh})$ to remove coarse and fine soil particules. The material remaining on the fine sieve was placed in a flotation cylinder where hollow spore coats and detritus were separated from soil particles and live spores by flotation in water. The detritus and dead spores were removed by displacing the floating material and water with $50 \%$ (vol/vol) glycerol. Remaining spores were separated from the soil by bubbling compressed air through the glycerol-soil suspension for $1.0 \mathrm{~min}$ and allowing the soil particles to settle to the bottom (15 min) (Furlan and Fortin 1975). Following removal of the spore suspension, spores were washed, then counted under the dissecting microscope. The number of spores in $100 \mathrm{~g}$ wet soil was corrected for moisture content to give the number of spores in $100 \mathrm{~g}$ dry soil. (The efficiency of this procedure for Saskatchewan field soils was $86.5 \pm 5.1 \%$ compared with a value of $94.5 \%$ reported by Furlan and Fortin (1975) for sieved laboratory soil.)

Plant roots were analyzed for the degree of VAM colonization after clearing with $10 \%$ $\mathrm{KOH}$ and staining in $0.01 \%$ acid fuschin in lactophenol (Furlan and Fortin 1973). Stained root 
segments (24 per plant) were examined microscopically for the presence of VAM fungal structures.

\section{Field Studies}

Soil samples were obtained from 16 sites throughout central and east-central Saskatchewan during the first half of the growing season (May, June, early July) and analyzed for the presence of mycorrhizal spores and $\mathrm{NaHCO}_{3}$ extractable P (Hamm et al. 1970). Sampling sites were chosen on the basis of soil series, topography, and proximity to comparable virgin sites. At each site, three composite samples were removed from wheat fields and three from comparable virgin sites under native grasses to determine spore population and the effect of cultivation on the VAM fungi. Samples from virgin and cultivated fields at each site were taken on the same day. Each composite sample was composed of 10 subsamples taken with a $2.5-\mathrm{cm}$ corer at $10-\mathrm{m}$ intervals along a straight line to a depth of $15 \mathrm{~cm}$.

The effect of summer-fallowing on mycorrhizal spore populations was determined on two soil series (Canora and Hoey) by comparing samples from summer-fallow fields with fields cropped to wheat (Triticum aestivum L.), barley (Hordeum vulgare L.), and rapeseed (Brassica campestris var. Torch). The Hoey soil was sampled in early May; the Canora soil was sampled in mid-July.

The seasonal variation of spore populations was measured by sampling, every 14 days during the growing season, a separate Oxbow loam soil planted to wheat and a comparable virgin grassland.

The effect of phosphorus fertilization on VAM root colonization in the field was studied using faba beans (Vicia faba L.) grown under irrigated conditions in an Elstow loam (Dark Brown Chernozemic $8 \mu \mathrm{g} \mathrm{P} \cdot \mathrm{g}^{-1}$ soil) in a replicated experiment receiving four treatments $(0$, 15,30 , and $45 \mathrm{~kg} \mathrm{P} \cdot \mathrm{ha}^{-1}$ ). Roots and soil were sampled after 11 wk growth (early August). Three plants were sampled from each of four plots on each treatment. Roots were analyzed for the degree of colonization (Ambler and Young 1977), and soils for the number of VAM fungal spores as previously described.

\section{Inoculation Studies}

GROWTH CHAMBER EXPERIMENTS. Surface soil was collected from a summer-fallow field (Ox- bow loam, Black Chernozemic) previously planted to wheat. Soil was dried and ground to pass through a $2-\mathrm{mm}$ sieve and stored air dried. In this condition, it contained: $6.9 \mu \mathrm{g} \mathrm{P} \cdot \mathrm{g}^{-1}, 21$ $\mu \mathrm{m} \mathrm{NO} \mathrm{NO}_{3}-\mathrm{N} \cdot \mathrm{g}^{-1}$, and 16 mycorrhizal spores per $100 \mathrm{~g}$ of dry soil. Plastic pots (4.5-L) were filled with $3200 \mathrm{~g}$ soil. Faba bean seeds were surface sterilized (10 min) in $10 \%$ sodium hypochlorite, pregerminated, and planted $3 \mathrm{~cm}$ below the surface of the soil.

Inoculum for each pot consisted of ca. $3 \mathrm{~g}$ of dried onion roots, colonized with $G$. mosseae (Nicol and Gerd.), and adhering soil. These and dried uncolonized roots for controls were placed $5 \mathrm{~cm}$ below the seed at the time of planting. A subsample of the isolated fungus was identified as G. mosseae by V. Furlan. All seeds were sprinkled with a commercial preparation of $R h i$ zobium leguminosarum (Legume Aid, Agricultural Laboratories Inc., Columbus, Ohio) at the time of planting.

Plants were watered daily with distilled water to $90 \%$ of field capacity. Humidity was maintained at $50 \%$. Light levels were kept at $19 \mathrm{klx}$ for the first experiment and $15 \mathrm{klx}$ for the second experiment, using a light:dark period of $16: 8 \mathrm{~h}$ with corresponding temperatures of 24 and $20^{\circ} \mathrm{C}$

In the first experiment the effect of $\mathrm{P}$ was studied at two levels: 0 and $11 \mu \mathrm{g} \mathrm{P} \cdot \mathrm{g}^{-1}$ soil with ${ }^{32} \mathrm{P}$ added at a rate of $0.57 \mu \mathrm{Ci} \cdot \mathrm{mg}^{-1} \mathrm{P}$. In the second experiment rates of 0,25 and $50 \mu \mathrm{g}$ $\mathrm{P} \cdot \mathrm{g}^{-1}$ soil were used in the second experiment. The plants were harvested after 8 wk growth and were analyzed for VAM root colonization, shoot and root weights, P content (Hesse 1971), and ${ }^{32} \mathrm{P}$ content. ${ }^{32} \mathrm{P}$ uptake was measured by liquid scintillation counting after acid digestion of plant material. A PPO-POPOP-Triton X-100 mixture was used as scintillant (Rennie and Paul 1971).

\section{Field Inoculation Studies}

Four field inoculation experiments were run during the 1980 growing season. Details on each of the site locations are given in Table 1 . At each site, 60 cylinders $(20-\mathrm{cm}$ diam., $35 \mathrm{~cm}$ long) were pushed into the soil to a depth of 30 $\mathrm{cm}$. The top $20 \mathrm{~cm}$ of soil was removed from all cylinders, thoroughly mixed, and replaced. Phosphorus, VAM, and rhizobial inoculum were added in the same manner as for growth chamber experiments. Ten cylinders were used for each treatment, i.e., zero, medium and high 
Table 1. Field site data for VAM inoculation studies in 1980

\begin{tabular}{|c|c|c|c|c|c|c|c|}
\hline \multirow[b]{3}{*}{ Site } & \multirow{3}{*}{$\begin{array}{c}\text { Soil type } \\
\text { (Chernozemic) }\end{array}$} & \multicolumn{3}{|c|}{$\begin{array}{l}\text { Soil data before experiment } \\
\qquad\left(\mu \mathrm{g} \cdot \mathrm{g}^{-1} \text { soil }\right.\end{array}$} & \multirow{3}{*}{$\begin{array}{l}\text { VAM spores } \\
/ 100 \mathrm{~g} \text { soil }\end{array}$} & \multirow{2}{*}{\multicolumn{2}{|c|}{$\begin{array}{c}\text { P added } \\
\left(\mu \mathrm{g} \mathrm{P} \cdot \mathrm{g}^{-1} \text { soil }\right)\end{array}$}} \\
\hline & & \multirow{2}{*}{$\begin{array}{c}\text { Mineral } \\
\mathrm{N}\end{array}$} & \multirow{2}{*}{$\begin{array}{c}\mathrm{NaHCO}_{3} \\
\text { extractable } \\
\mathrm{P}_{2} \mathrm{O}_{5}\end{array}$} & \multirow[b]{2}{*}{$\mathrm{K}_{2} \mathrm{O}$} & & & \\
\hline & & & & & & Med. & High \\
\hline Irrig. 1 & D. Brown & 8 & 8.5 & 225 & 30 & 9 & 18 \\
\hline Irrig. 2 & D. Brown & 5 & 7.5 & 275 & 23 & 9 & 18 \\
\hline Irrig. 3 & D. Brown & 3 & 5 & 185 & 15 & 9 & 18 \\
\hline Dryland & Black & 9.5 & 6 & 370 & 42 & 5.5 & 11 \\
\hline
\end{tabular}

$\mathrm{P}$ levels, + and - VAM. $\mathrm{P}$ was added as an $\mathrm{NH}_{4} \mathrm{H}_{2} \mathrm{PO}_{4}$ solution. Medium levels of $\mathrm{P}$ addition were $5.5 \mu \mathrm{g} \mathrm{P} \cdot \mathrm{g}^{-1}$ soil and $9 \mu \mathrm{g} \mathrm{P} \cdot \mathrm{g}^{-1}$ soil for dryland and irrigated sites, respectively. High levels of $\mathrm{P}$ addition were 11 and $18 \mu \mathrm{g}$ $\mathrm{P} \cdot \mathrm{g}^{-1}$ soil for dryland and irrigated sites, respectively. All treatments received a total of $8.13 \mu \mathrm{g} \mathrm{N} \cdot \mathrm{g}^{-1}$ soil. At each irrigated site, ${ }^{32} \mathrm{P}$ $\left(17.8 \mu \mathrm{Ci} \cdot \mathrm{mg}^{-1} \mathrm{P}\right)$ was added to half the cylinders in each medium and high $P$ level treatment. Four $V$. faba plants were grown in each cylinder. ${ }^{32} \mathrm{P}$-labelled plants were harvested after 8 wk growth and were analyzed for shoot weight, total $\mathrm{P}$ and ${ }^{32} \mathrm{P}$ content. The remaining cylinders were harvested at maturity and analyzed for seed dry matter production.

\section{RESULTS}

\section{Spore Population Enumeration}

The number of VAM mycorrhizal spores extracted from virgin soils exceeded the number of spores extracted from cultivated soils by 1.1-33.5 times (average 4.8) (Table 2). There was no significant relationship between the numbers of mycorrhizal spores and soil series, Great Soil Group, or P content of the soil.

One year of summer-fallowing a Canora soil previously planted to wheat reduced the VAM spore population in that soil to $60 \%$ of the level found in the Canora soil planted to wheat (Table 3). Similar results were obtained in a Hoey soil sampled at the beginning of the growing season. A second year of summer-fallow on the Hocy sites reduced the spore population to $43 \%$ of the previous year or $16.5 \%$ of the level found in unfallowed soil.
One year of rapeseed cropping reduced the VAM spore population at the Hoey site to the same level as 1 yr of summer-fallow (Table 3). Substitution of barley for wheat had no effect on the spore population at the Canora site.

Spore populations in a virgin (native grassland) soil did not increase overall during the growing season, although large fluctuations in the population levels were observed (Fig. 1). However, spore population levels in a cultivated soil (wheat) increased once the crop became established and eventually surpassed population levels found in the adjacent virgin soil.

Addition of $\mathrm{P}$ fertilizer to soils was another aspect of crop production that was

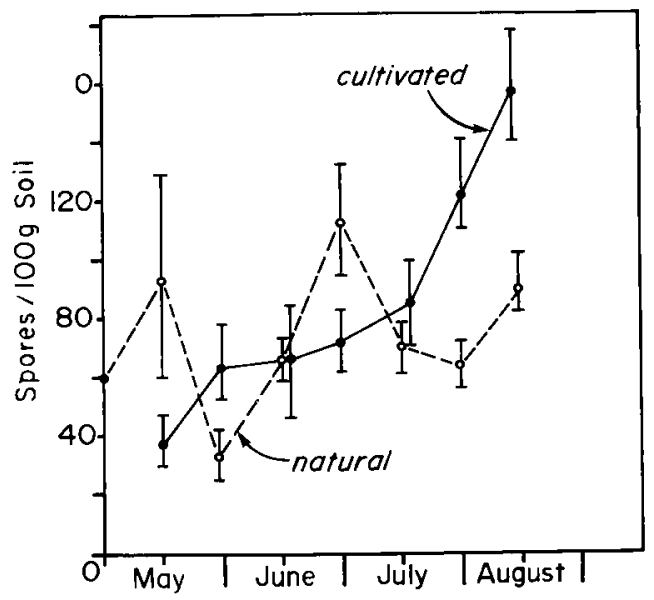

Fig. 1. Mycorrhizal spore populations in an Oxbow soil under natural grass and cultivated (wheat) conditions over the growing season (I $=$ standard deviation). 
Table 2. Numbers of VAM spores extracted from various Saskatchewan soils

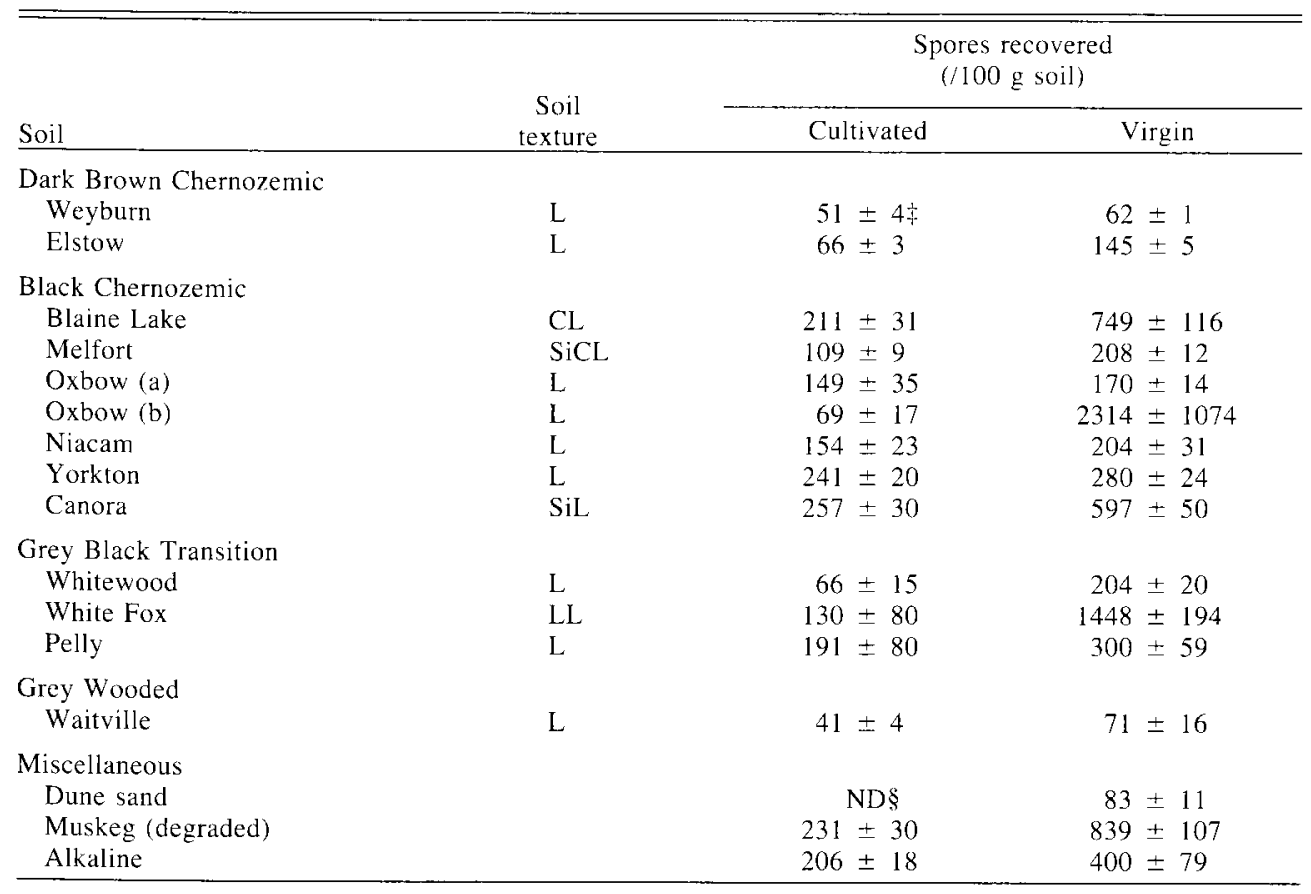

$\succ$ Sites sampled in May, June and early July.

$\doteqdot$ Standard deviation.

$\$$ No data.

found to affect the VAM fungi population. Faba bean roots near the end of the growing season had relatively high levels $(47 \%)$ of VAM colonization in nonfertilized soil but the addition of $45 \mathrm{~kg} \mathrm{P} \cdot \mathrm{ha}^{-1}$ to the soil reduced the colonization levels to $15 \%$ (Fig. 2). The number of spores extracted from soils fertilized with $45 \mathrm{~kg} \mathrm{P} \cdot \mathrm{ha}^{-1}$ was less than half the number of spores extracted from nonfertilized soils.

\section{Effect of Inoculation of Faba Beans with G. mosseae}

$G$. mosseae colonization increased shoot weights, total $\mathrm{P}$ uptake, and the degree of root colonization above that for the uni-

Table 3. Comparative effects of cropping and fallowing on VAM spore populations

\begin{tabular}{llc}
\hline \hline $\begin{array}{c}\text { Soil type } \\
\text { and location }\end{array}$ & Land use & Spores \\
\hline Canora SiL (Canora) & Wheat & $300 \pm 21^{\dagger}$ \\
(sampled 15 July 1977) & Barley & $326 \pm 14$ \\
& 1-yr summer-fallow & $189 \pm 23$ \\
Hoey SiCL (Hagen) & Barley stubble & $332 \pm 35$ \\
(sampled 5 May 1978) & 1-yr summer-fallow & $127 \pm 20$ \\
& 2-yr summer-fallow & $55 \pm 9$ \\
& Rapeseed & $104 \pm 37 \ddagger$ \\
\hline
\end{tabular}

$\uparrow$ Standard deviation.

末On fields previously planted to barley. 
Table 4. Effect of inoculation with $G$. mosseae on faba bean dry matter yield and P uptake from nonsterile soil

\begin{tabular}{|c|c|c|c|c|c|c|}
\hline & \multirow{3}{*}{$\begin{array}{c}\text { Glomus } \\
\text { inoculated }\end{array}$} & \multicolumn{5}{|c|}{$\mathrm{P}$ additions $\left(\mu \mathrm{g} \mathrm{P} \cdot \mathrm{g}^{-1}\right.$ soil $)$} \\
\hline & & \multicolumn{2}{|c|}{ Experiment 1} & \multicolumn{3}{|c|}{ Experiment 2} \\
\hline & & $0^{\dagger}$ & $11 \div$ & $0 \div$ & $25 \ddagger$ & $50+$ \\
\hline $\begin{array}{l}\text { Total aboveground } \\
\text { shoot mass }(g)\end{array}$ & $\begin{array}{l}- \\
+\end{array}$ & $\begin{array}{l}7.91 a \\
9.61 b\end{array}$ & $\begin{array}{l}12.7 c \\
15.2\end{array}$ & $\begin{array}{l}3.40 a \\
6.43 b\end{array}$ & $\begin{array}{l}10.9 c \\
14.6\end{array}$ & $\begin{array}{l}12.6 d \\
14.8\end{array}$ \\
\hline $\begin{array}{l}\text { Total P in shoot } \\
\text { (mg/shoot) }\end{array}$ & $\begin{array}{l}- \\
+\end{array}$ & $\begin{array}{l}8.20 a \\
9.30 b\end{array}$ & $\begin{array}{l}13.8 c \\
17.4\end{array}$ & $\begin{array}{l}2.44 a \\
5.00 b\end{array}$ & $\begin{array}{l}5.91 c \\
9.27\end{array}$ & $\begin{array}{l}7.50 d \\
10.4\end{array}$ \\
\hline $\begin{array}{l}\% \text { fertilizer } \\
\text { utilized }\end{array}$ & + & - & $\begin{array}{l}27.7 a \\
36.2 b\end{array}$ & - & $\begin{array}{l}- \\
-\end{array}$ & - \\
\hline $\begin{array}{l}\% \text { of roots } \\
\text { infected }\end{array}$ & + & $\begin{array}{l}24.0 a \\
32.7 b\end{array}$ & $\begin{array}{l}13.7 c \\
18.3\end{array}$ & $\begin{array}{l}20.4 a \\
74.7 b\end{array}$ & $\begin{array}{l}7.20 \mathrm{C} \\
35.7\end{array}$ & $\begin{array}{l}5.00 d \\
16.3 \\
\end{array}$ \\
\hline
\end{tabular}

$\doteqdot$ Plants grown in $19 \mathrm{klx}$.

$\div$ Plants grown in $15 \mathrm{klx}$.

$a-d$ Denotes rows and columns with significant differences $(P<0.05)$.

oculated plants (Table 4). VAM plants inoculated with $G$. mosseae showed only slight growth increases with $\mathrm{P}$ additions above $25 \mu \mathrm{g} \mathrm{P} \cdot \mathrm{g}^{-1}$ soil. Addition of $50 \mu \mathrm{g}$ $\mathrm{P} \cdot \mathrm{g}^{-1}$ soil increased the shoot weights of uninoculated plants above those in the 25 $\mu \mathrm{g} \mathrm{P} \cdot \mathrm{g}^{-1}$ soil treatment, but the shoot weights in this treatment were still less than those obtained for plants inoculated with $G$. mosseae with $25 \mu \mathrm{g} \mathrm{P} \cdot \mathrm{g}^{-1}$ soil. Addition of $P$ reduced the degree of root colonization for both cases.

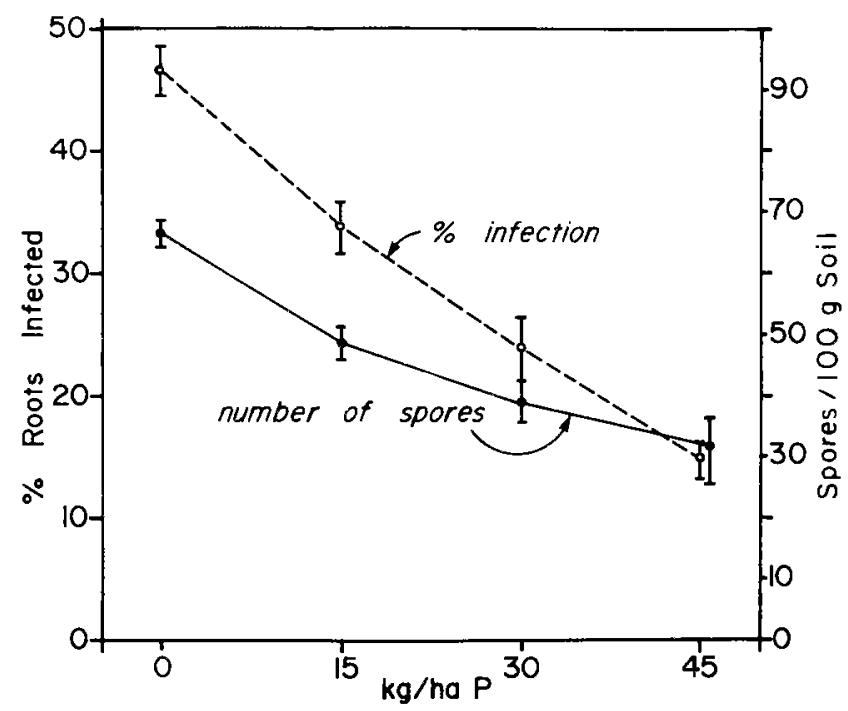

Fig. 2. Effect of added phosphorus on mycorrhizal root colonization and spore production on faba beans $(I=$ standard deviation $)$. 
Inoculation of field site cylinders also resulted in an increased production of seed and shoot dry matter in most cases (Table 5). Fertilizer was more fully utilized by noninoculated plants. This, coupled with the finding that more $\mathrm{P}$ was contained in inoculated plant shoots, means that a greater amount of soil $\mathrm{P}$ was taken up by inoculated plant roots. Indeed, the ratio of fertilizer $\mathrm{P}$ absorbed to soil $\mathrm{P}$ absorbed, as determined by subtracting plant fertilizer $\mathrm{P}$ from plant total $\mathrm{P}$, was much lower for inoculated treatments. Inoculation did not significantly affect plant $P$ concentrations.

\section{DISCUSSION}

The VAM spore populations of both virgin and cultivated soils in this study were large enough at the beginning of the growing season to serve as inoculum for susceptible plant roots. Cultivation of a soil alters many abiotic parameters of the soil which, in turn, affect the biological components. Differences in the soil environment may impose different pressures on VAM fungi in virgin and cultivated soils causing differences to occur in their levels of spore production. Virgin soils may contain nonsporing species of VAM fungi (Mosse and Bowen 1968) or species using vesicles as resting structures (Schenck and Smith 1982). Conditions in cultivated soils, especially those that were fallowed the previous season, may prevent these species or varieties from maintaining their population levels and so, in cultivated soils, the VAM

Table 5. Effect of inoculation with $G$. mosseae on faba bcan seed and shoot dry mass and $P$ uptake in the field

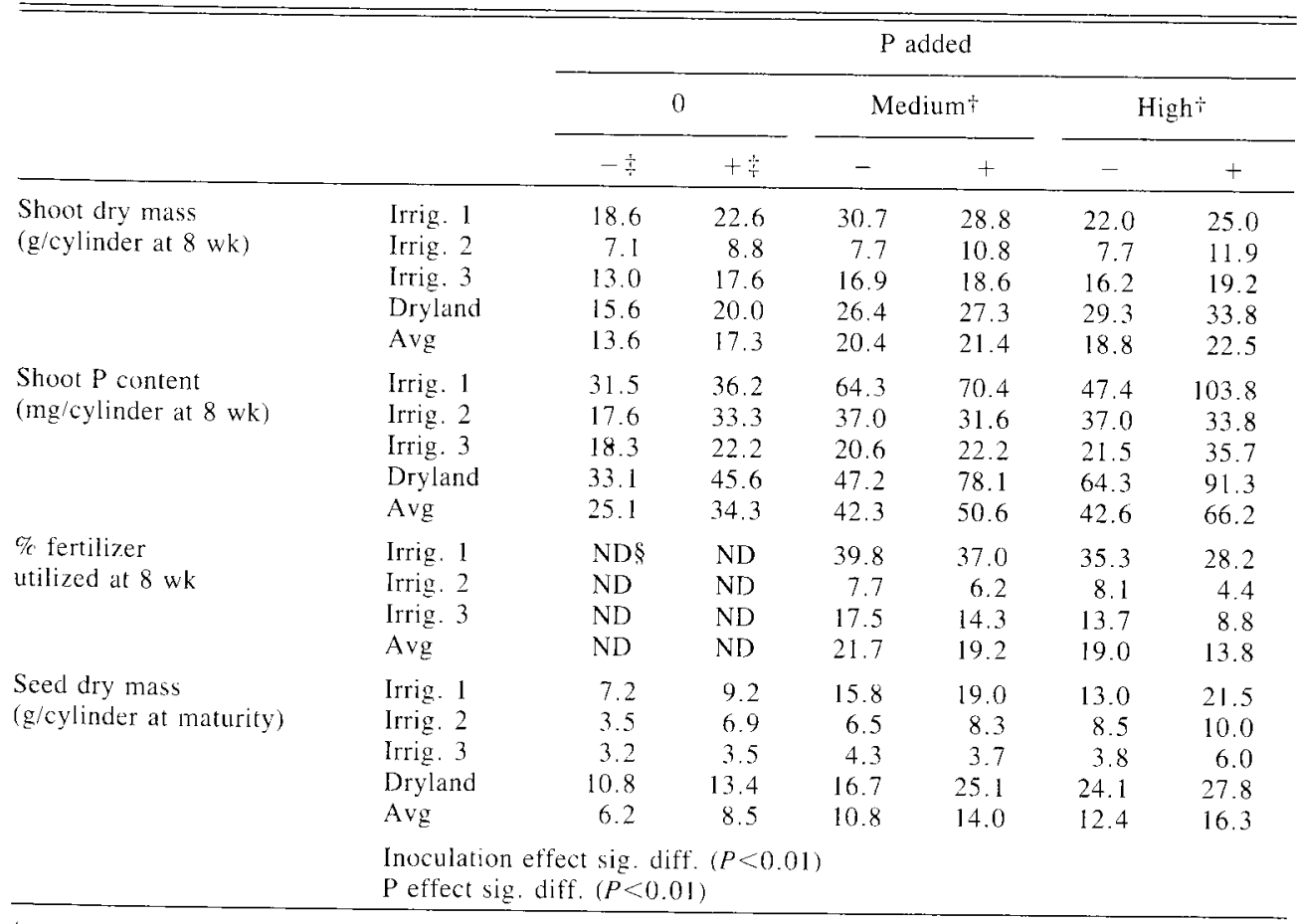

TMedium: dryland, $5.5 \mu \mathrm{g} \mathrm{P} \cdot \mathrm{g}^{-1}$ soil; irrigated, $9 \mu \mathrm{g} \mathrm{P} \cdot \mathrm{g}^{-1}$ soil. High: dryland, $11 \mu \mathrm{g} \mathrm{P} \cdot \mathrm{g}^{-1}$ soil; irrigated, 18 $\mu \mathrm{g} P \cdot \mathrm{g}^{-1}$ soil.

$\doteqdot G$. mosseae inoculum

$\$$ No data. 
may have had to produce chlamydospores to survive. If our sampling dates had been later in the growing season, the differences between spore populations in virgin and cultivated soils may not have been as great, or may have even been reversed.

Many factors tend to favor certain species of VAM over others (Greene et al. 1976). Natural selection will cause certain species to propagate more quickly and become more prevalent in certain areas. Cultivation may produce soil conditions beneficial to a VAM fungus that is not the best fungus for a particular crop. In such cases, inoculation with beneficial VAM fungi that could attain a reasonable degree of colonizaton could increase crop growth or at least maintain it with less added P. Similarly, fields that have been cultivated for a long time, or have been sown to cruciferous crops, may have low levels of VAM fungi and would benefit from mycorrhizal inoculation. Not all fields will benefit from mycorrhizal inoculation, but as the cost of phosphorus fertilizer increases, the possibility that mycorrhizal fungi may aid in $\mathrm{P}$ uptake is economically attractive.

Mycorrhizal plants often grow better than nonmycorrhizal plants of the same species. The $G$. mosseae isolate selected and used in pot and field experiments was not chosen for its growth-enhancing effects, but for its ability to colonize faba bean roots at a high rate. Fortunately, this isolate was also an efficient supplier of $\mathrm{P}$ to faba bean roots. The soil used in pot experiments in this study was obtained from a wheat field. Consequently, any natural selection of fungal strains was done by wheat plants, resulting in the predominant strain in the soil probably not being the most efficient species for use with faba beans. Inoculation of the soil with G. mosseae supplied the faba beans with a large number of propagules of an efficient fungus.

Introduced VAM symbioses increased fertilizer $P$ use above indigenous symbioses in greenhouse soil. Since the fungi acquired $P$ from the available $P$ sources, it was not surprising to find increased fertilizer $P$ uptake. In the field, however, we found a decrease in fertilizer $P$ use with inoculation. The reason for this discrepancy is not understood but may be a function of the total root space for each plant. In pots, roots are constricted and must take up what is present. In the field, roots and fungal hyphae are free to explore soil further from the seeding location, or have a larger pool of soil $\mathrm{P}$ to feed from.

High additions of $\mathbf{P}$ to soils reduced the degree of VAM root colonization thereby negating some of the potential benefit of the mycorrhizal symbioses. Plant shoots obtain soil $P$ through the VAM fungi and the host root system, but as the levels of available $P$ increase, the degree of VAM colonization decreases because of the negative effect $P$ has on mycorrhizal colonization levels. High additions of $P$ fertilizer allow for maximum host growth without VAM colonizaiton, but because of increased $P$ uptake by mycorrhizal roots, moderate $\mathrm{P}$ fertilizer applications should maintain VAM colonization and still allow the same growth of the host. Addition of $P$ above the level needed for maximum benefits from both fertilizer P and VAM colonization is, in essence, replacing nature with expensive technology.

AMBLER, J. R. and YOUNG, J. L. 1977. Techniques for determining root length infected by vesicular-arbuscular mycorrhizac. Soil Sci. Soc. Am. J. 41: 551-556.

DAFT, M. J. and EL GIAHMI, A. A. 1978. Effect of arbuscular mycorrhizae on plant growth. VIII. Effects of defoliation and light on selected hosts. New Phytol. 80: 365-372.

FURLAN, V. and FORTIN, J. A. 1973. Formation of endomycorrhizae by Endogone calospora on Allium cepa under three temperature regimes. Natur. Can. 100: 467-477.

FURLAN, V. and FORTIN, J. A. 1975. A flotation bubbling system for collecting endogonaceous spores from sieved soil. Natur. Can. 102: 663-667.

FURLAN, V. and FORTIN, J. A. 1977. Effects of light intensity on the formation of vesicular- 
arbuscular endomycorrhizas on Allium cepa by Gigaspora calospora. New Phytol. 79: 335-340.

GERDEMANN, J. W. 1964. The effect of mycorrhizae on the growth of maize. Mycologia 56: 342-349.

GREENE, N. E., GRAHAM, S. O. and SCHENCK, N. C. 1976. The influence of $\mathrm{pH}$ on the germination of vesicular-arbuscular spores. Mycologia 68: 929-933.

HAMM, J. W., RADFORD, F. G. and HALSTEAD, E. H. 1970. The simultaneous determination of nitrogen, phosphorus, and potassium in sodium bicarbonate. Adv. Auto. Anal. 2: $65-69$.

HAYMAN, D. S., JOHNSON, A. M. and RUDDLESDIN, I. 1975. The influence of phosphate and crop species on endogone spores and vesicular-arbuscular mycorrhizae under field conditions. Plant Soil 43: 489-495.

HESSE, P. R. 1971. Texbook of soil chemical analyses. Ch. 12. Chem. Publ.

LAMBERT, D. H., BAKER, D. E. and COLE, H. Jr. 1979. The role of mycorrhizae in the interactions of phosphorus with zinc, copper, and other elements. Soil Sci. Soc. Am. J. 43: 976-980

MARONEK, D. M. 1981. Mycorrhizal fungi and their importance in horticultural crop production. Ch. 5, Pages 172--213 in Horticultural Reviews, AVI Publ. Co., Westport, Conn.

MOSSE, B. and BOWEN, G. D. 1968. The distribution of Endogone spores in some Australian and New Zealand soils and in an experimental soil at Rothamsted. Trans. Br. Mycol. Soc. 51: 485-492.

POWELL, C. L. 1977. Mycorrhizas in hill country soils. Effect of several mycorrhizal fungi on clover growth in sterilized soils. N.Z. J. Agric. Res. 20: 59-62.
POWELL, C. L. and DANIEL, J. 1978. Growth of white clover in undisturbed soils after inoculation with efficient mycorrhizal fungi. N.Z. J. Agric. Res. 21: 675-681.

RENNIE, D. A. and PAUL, E. A. 1971. Isotope methodology and techniques in soil-plant nutrition and plant physiology. Sask. Inst. Pedol. Publ. No. 76.

RHODES, L. H. and GERDEMANN, J. W. 1978. Hyphal translocation and uptake of sulfur by vesicular-arbuscular mycorrhizae of onion. Soil Biol. Biochem. 10: 355-360.

ROSS, J. P. 1971. Effect of phosphate fertilization on yield of mycorrhizal and non-mycorrhizal soybeans. Phytopathology 61: 1400-1403.

SAIF, S. R. and KHAN, A. G. 1975. The influence of season and stage of development of plant on Endogone mycorrhizae of field grown wheat. Can. J. Microbiol. 21: 1020-1024.

SAIF, S. R., SHEIKH, N. A. and KHAN, A. G. 1975. Ecology of Endogone. I. Relationship of Endogone spore populations with physical soil factors. Islamabad J. Sci. 2: 1-5

SCHENCK, N. C. and SCHRODER, V. N. 1974. Temperature responses of Endogone mycorrhizae on soybean roots. Mycologia 66: 600-605

SCHENCK, N. C. and SMITH, G. S. 1982. Additional new and unreported species of mycorrhizal fungi (Endogonaceae) from Florida. Mycologia 74: 77-92.

SHEIKH, N. A., SAIF, S. R. and KHAN, A. G. 1975. Ecology of Endogone. II. relationship of Endogone spore populations with chemical soil factors. Islamabad J. Sci. 2: 6-9.

SMITH, T. F. 1980. The effect and crop rotation on the abundance of spores of vesiculararbuscular (V-A) mycorrhizal endophytes. Plant Soil 57: 475-479. 